
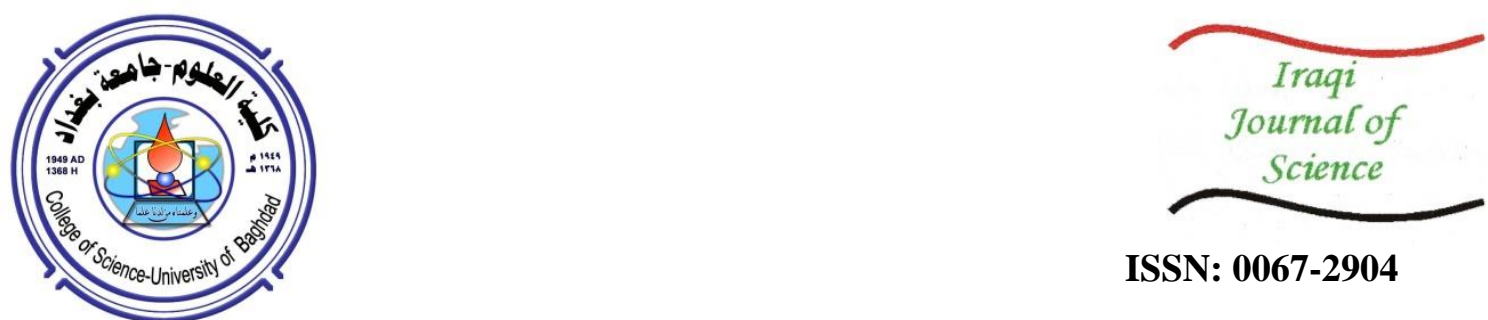

ISSN: 0067-2904

\title{
Changes in Serum Levels of Lipid Profile Parameters and Proteins in Toxoplasma gondii Seropositive Patients
}

\author{
Hayder Z. Ali, Harith Saeed Al-Warid* \\ Department of Biology, College of Science, University of Baghdad, Baghdad, Iraq
}

Received: 11/7/2020

Accepted: 31/8/2020

\begin{abstract}
The influence of Toxoplasma gondii on some biochemical parameters has lately gained an increasing attention. The aim of this study was to assess the levels of some biochemical parameters in Toxoplasma positive and negative subjects. An analytical case-control study was achieved in Baghdad for the period from October 2018 until March 2019. Forty nine females participated in this study, with an age range of 1855 years. The participants were separated into two groups, namely Toxoplasma positive subjects $(\mathrm{n}=21)$ and Toxoplasma negative subjects $(\mathrm{n}=28)$, based on enzyme-linked immunosorbent assay (ELISA). Blood and serum samples were collected from all subjects to evaluate the serum levels of cholesterol, triglycerides, high density lipoprotein (HDL), very low density lipoprotein (VLDL), low density lipoprotein (LDL), total protein, total globulin and total albumin. The results showed non-significant differences between Toxoplasma positive and negative subjects for all the parameters, although cholesterol levels were lower (mean $149 \mathrm{mg} / \mathrm{dL}$; range 131.9-165.9 mg/dL) in Toxoplasma positive patients as compared to those in Toxoplasma negative subjects $(161 \mathrm{mg} / \mathrm{dL} ; 146.7-175 \mathrm{mg} / \mathrm{dL})$. In addition, triglycerides levels were lower $(160 \mathrm{mg} / \mathrm{dL} ; 123.3-196.8 \mathrm{mg} / \mathrm{dL})$ in Toxoplasma positive subjects as compared to the control subjects $(165 \mathrm{mg} / \mathrm{dL} ; 134.2-195.3$ $\mathrm{mg} / \mathrm{dL}$ ). The only significant difference was noticed among subjects with an age range of 26-35 years, where globulin level was significantly higher $(\mathrm{p}=0.023)$ in Toxoplasma negative subjects as compared to that in Toxoplasma positive subjects.
\end{abstract}

Keywords: biochemical parameters, Toxoplasma gondii, women

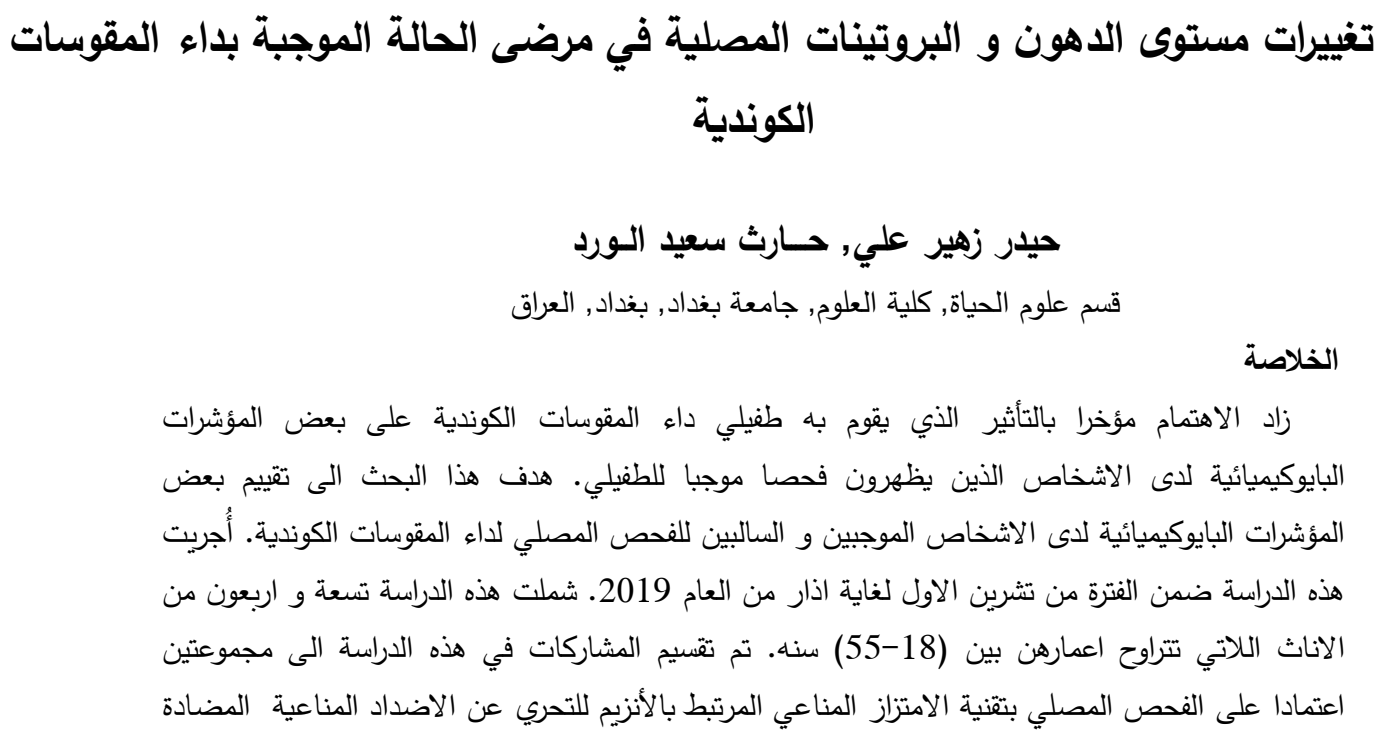

*Email: harith.saeed@sc.uobaghdad.edu.iq 


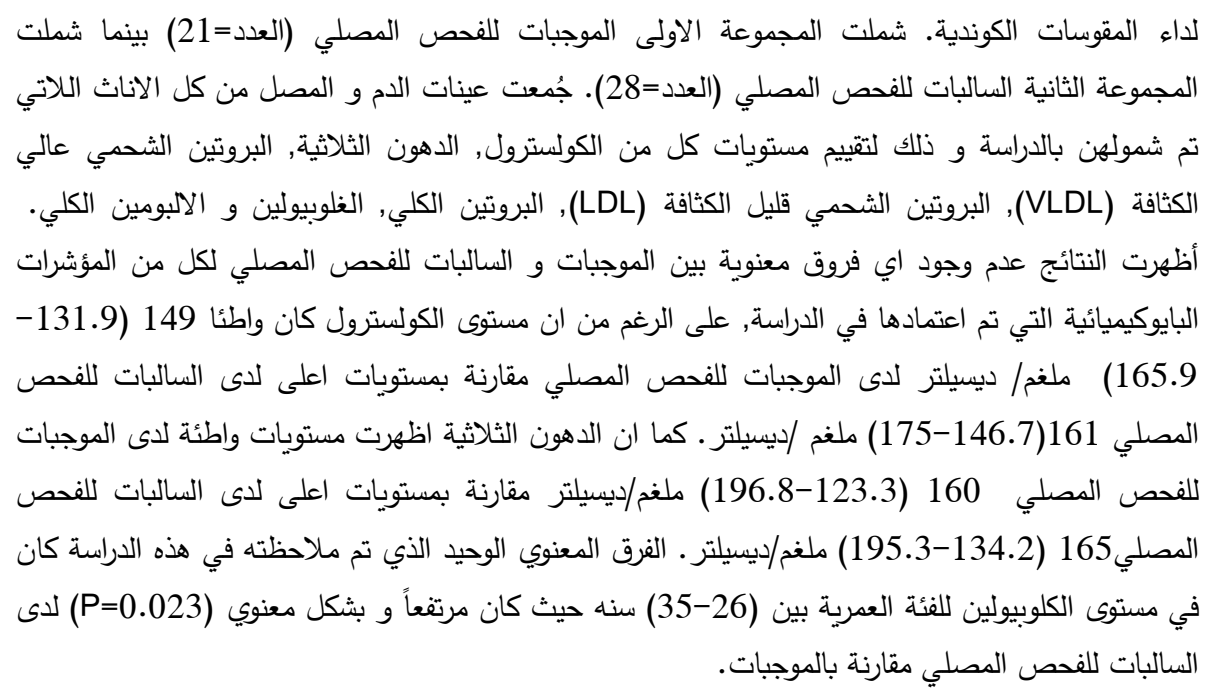

\section{Introduction}

Toxoplasmosis is an infection caused by a member of the Apicomplexa eukaryotes, namely Toxoplasma gondii. Toxoplasmosis is a cosmopolitan infection of humans and other warm-blooded animals. This protozoan parasite is of remarkable public health and economic concern [1]. Infections initiated by $T$. gondii continue to cause major public health problems as they can cause various clinical outcomes, such as abortion, retino-choroiditis, hydrocephalus, mental retardation, and even fatal death and life-threatening encephalitis in people with AIDS, organ transplantation, and immunosuppressive therapy $[2,3]$. Globally, it has been estimated that $T$. gondii infection affects $30 \%$ to $65 \%$ of the entire global population [4]. The sero-prevalence of $T$. gondii infection in humans increases with age, but it does not differ significantly between the sexes and is lower in cold regions [5].

Recently, focusing on Toxplasmosis has increased dramatically in Iraq through several studies [6, 7]. The involvement of serum biochemical parameters, e.g. the levels of cholesterol, triglycerides, high density lipoprotein (HDL), very low density lipoprotein (VLDL), low density lipoprotein (LDL), total protein, total globulin, and total albumin, in humans infected with some parasites has attracted the attention of many investigators $[8,9]$. In-vitro studies revealed that such parasites can grow in lipidrich media without serum [10]. The aim of this study is to assess the levels of some biochemical parameters in Toxoplasma positive and negative subjects.

\section{Materials and methods}

\section{Subjects and Study design}

This research was an analytical case control study conducted from October 2018 until March 2019 .The population in this study was adult women who attended several hospitals, Primary Health Care centres, and private clinics. Sample collection was carried out by consecutive sampling with 49 participants who matched inclusion criteria and had no exclusion criteria. The inclusion criteria included adult women with age of less than 60 years, whereas exclusion criterion was pregnancy.

\section{Blood Samples}

Five $\mathrm{ml}$ of vein-blood was collected from each participant in a sterilized plain tube and left for 25 minutes at room temperature for clotting. The sample was then centrifuged at 2000xg for 12 minutes for serum collection, which was aspirated by using a micropipette, dispensed into a sterile tube, and stored at $-20^{\circ} \mathrm{C}$ until used for ELISA test.

\section{Detection of the anti-T. gondii IgG and anti-T. gondii IgM}

Serum samples were analysed for anti-T. gondii IgG antibodies with the enzyme immunoassay kit "Toxoplasma IgG" (Humman). Result equivalent or higher than $8 \mathrm{IU} / \mathrm{ml}$ was considered positive. Also, positive serum samples for anti-T. gondii IgG antibodies were screened for anti-T. gondii IgM antibodies by the available enzyme immunoassay "Toxoplasma IgM" kit (Humman). Both tests were applied after the instructions available with the kits. 


\section{Biochemical tests}

Triglycerides (TGS), cholesterol, and HDL levels were measured using a traditional enzymatic assay (Linear chemicals, Montgat-Barcelona, Spain). While, levels of LDL and VLDL were calculated using the following equations [11]:

$\mathrm{LDL}(\mathrm{mg} / \mathrm{dL})=$ Total Cholesterol-HDL - Triglycerides $(\mathrm{mg} / \mathrm{dL}) / 5$

$\operatorname{VLDL}(\mathrm{mg} / \mathrm{dL})=$ Triglycerides $(\mathrm{mg} / \mathrm{dL}) / 5$

Serum levels of total protein and albumin were measured by using the enzyme colorimetric method (Bio kit, Spain). Finally, serum globulin was measured by using protein electrophoresis [12].

\section{Statistical Analysis}

The results were stated as percentage and mean \pm standard deviation (SD). Data analysis was achieved by SPSS 16.0 (SPSS Inc., Chicago, IL, USA).The data were assessed by chi-square test and the Student's t-test $(\mathrm{t})$. $\mathrm{P}$ values $<0.05$ were considered statistically significant. Kappa value was used to assess the agreement between the IgG and IgM results.

\section{Results}

This study was designed as a case control study. The patients were divided into two groups according to their anti-toxoplasma IgG and/or IgM results. A substantial agreement between the levels of $\mathrm{IgG}$ and IgM was found and the Kappa value was 0.80 .

The first group was the Toxoplasma gondii positive group $(\mathrm{n}=20)$. The second group was $T$. gondii negative group $(n=29)$. The results of cholesterol levels are illustrated in Figure-1. The results demonstrated a non-significant difference of cholesterol level in the serum samples of $T$. gondii positive and T. gondii negative groups, although cholesterol levels were lower (149; 131.9-165.9 $\mathrm{mg} / \mathrm{dL})$ in $T$. gondii positive group as compared to $T$. gondii negative group $(161 ; 146.7-175 \mathrm{mg} / \mathrm{dL})$.

The results of triglyceride levels are shown in Figure-2. The results also demonstrated a nonsignificant difference of triglycerides in the serum samples of $T$. gondii positive and $T$. gondii negative groups, although the levels were lower $(160 ; 123.3-196.8 \mathrm{mg} / \mathrm{dL})$ in $T$. gondii positive group compared with $T$. gondii negative group $(165 ; 134.2-195.3 \mathrm{mg} / \mathrm{dL})$.

The results also showed a non-significant difference of cholesterol in the serum samples of $T$. gondii positive and $T$. gondii negative women for the different age groups (Table-1).

The results also showed non-significant differences of triglycerides in the serum samples of positive $T$. gondii and negative women for the different age groups.

The results revealed non-significant differences of HDL in the sera of T. gondii positive and $T$. gondii negative groups, although the level was slightly higher in $T$. gondii positive women (50.48 $\mathrm{mg} / \mathrm{dL}$ ) compared with $T$. gondii negative women $(48.86 \mathrm{mg} / \mathrm{dL}$ ) (Figure-3). These results were similar to those of serum levels of VLDL, which also presented no significant differences between $T$. gondii positive and T. gondii negative women, who showed very similar levels (32.76 and 32.31 $\mathrm{mg} / \mathrm{dL}$, respectively) (Figure-4). On the other hand, LDL was significantly decreased in the $T$. gondii positive women $(63.6 \mathrm{mg} / \mathrm{dL})$ as compared to $T$. gondii negative women $(80.99 \mathrm{mg} / \mathrm{dL})$ (Figure-5).

Globulin level was slightly lower in $T$. gondii positive women $(3.01 \mathrm{~g} / \mathrm{dL})$ compared with $T$. gondii negative women (3.47 g/ dL) (Figure-6). No significant difference was noticed between the two groups. A significant difference in globulin level was noticed between these two groups, but only at an age range of 26-35 years. Globulin level was significantly higher $(\mathrm{p}=0.023)$ in Toxoplasma negative subjects $(3.58 \mathrm{~g} / \mathrm{dL})$ as compared to Toxoplasma positive subjects $(2.88 \mathrm{~g} / \mathrm{dL})$ (Table- 6$)$.

Albumin level was significantly lower $(\mathrm{p}=0.007)$ in Toxoplasma positive subjects $(4.17 \mathrm{mg} / \mathrm{dL})$ versus a high level in Toxoplasma negative subjects $(4.75 \mathrm{mg} / \mathrm{dL})$. In addition, significant differences in albumin levels were noticed among these two groups at age ranges of 18-25 and 26-35 years (Table-7). On the other hand, no significant differences were noticed in total protein levels between Toxoplasma positive subjects $(7.5 \mathrm{mg} / \mathrm{dL})$ and Toxoplasma negative subjects $(7.71 \mathrm{mg} / \mathrm{d})$ (Figure- 8$)$. 


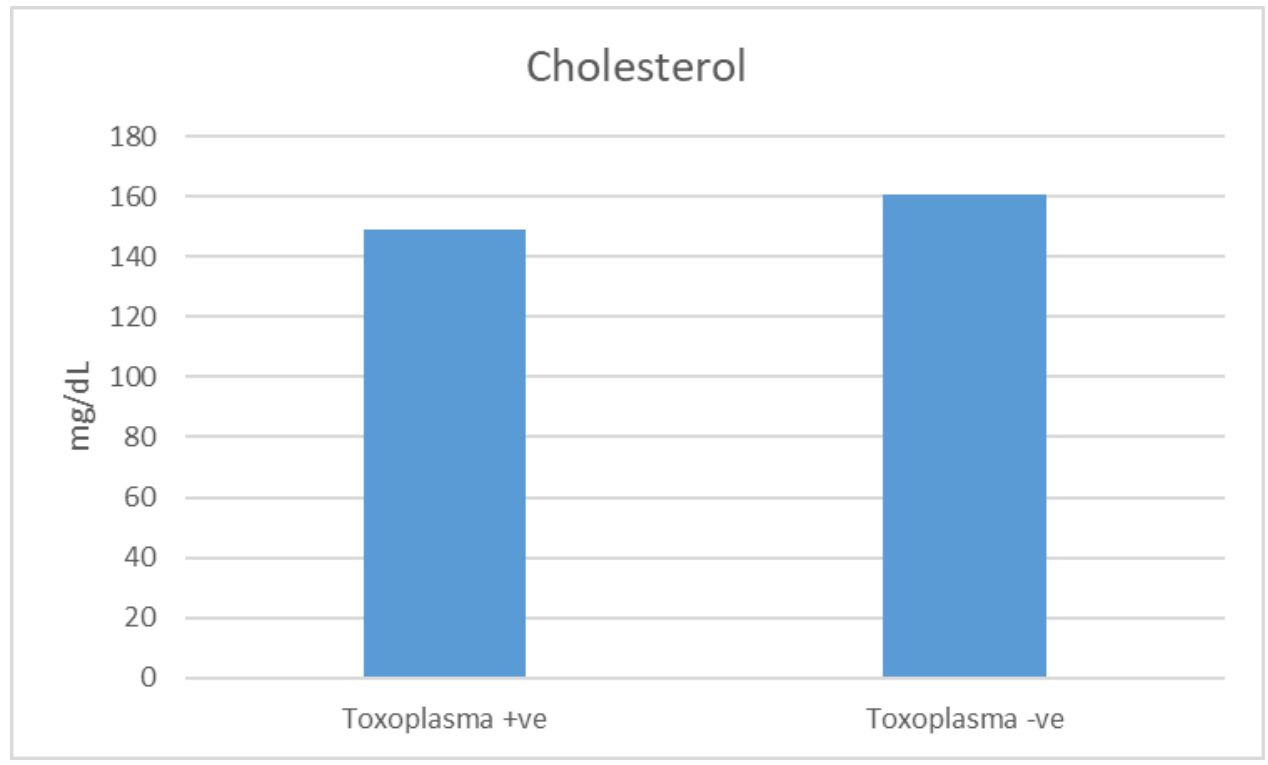

Figure 1-Cholesterol levels in Toxoplasma positive and Toxoplasma negative subjects.

Table 1- Cholesterol levels in Toxoplasma +ve and Toxoplasma -ve subjects in relation to age groups.

\begin{tabular}{|c|c|r|r|r|r|r|}
\hline Age/years & otal & $\begin{array}{c}\text { Toxoplasma } \\
+v e\end{array}$ & $\begin{array}{c}\text { Mean of } \\
\text { Cholesterol } \\
\text { level(mg/dL) }\end{array}$ & $\begin{array}{c}\text { Toxoplasma } \\
- \text { ve }\end{array}$ & $\begin{array}{c}\text { Mean of } \\
\text { Cholesterol } \\
\text { level (mg/dL) }\end{array}$ & $\begin{array}{c}\mathrm{p} \\
\text {-value }\end{array}$ \\
\hline $18-25$ & 5 & 7 & 144 & 8 & 183 & 22 \\
\hline $26-35$ & 3 & 12 & 147 & 11 & 159 & 0. \\
\hline $36+$ & 1 & 2 & 161 & 9 & 130 & 0. \\
\hline
\end{tabular}

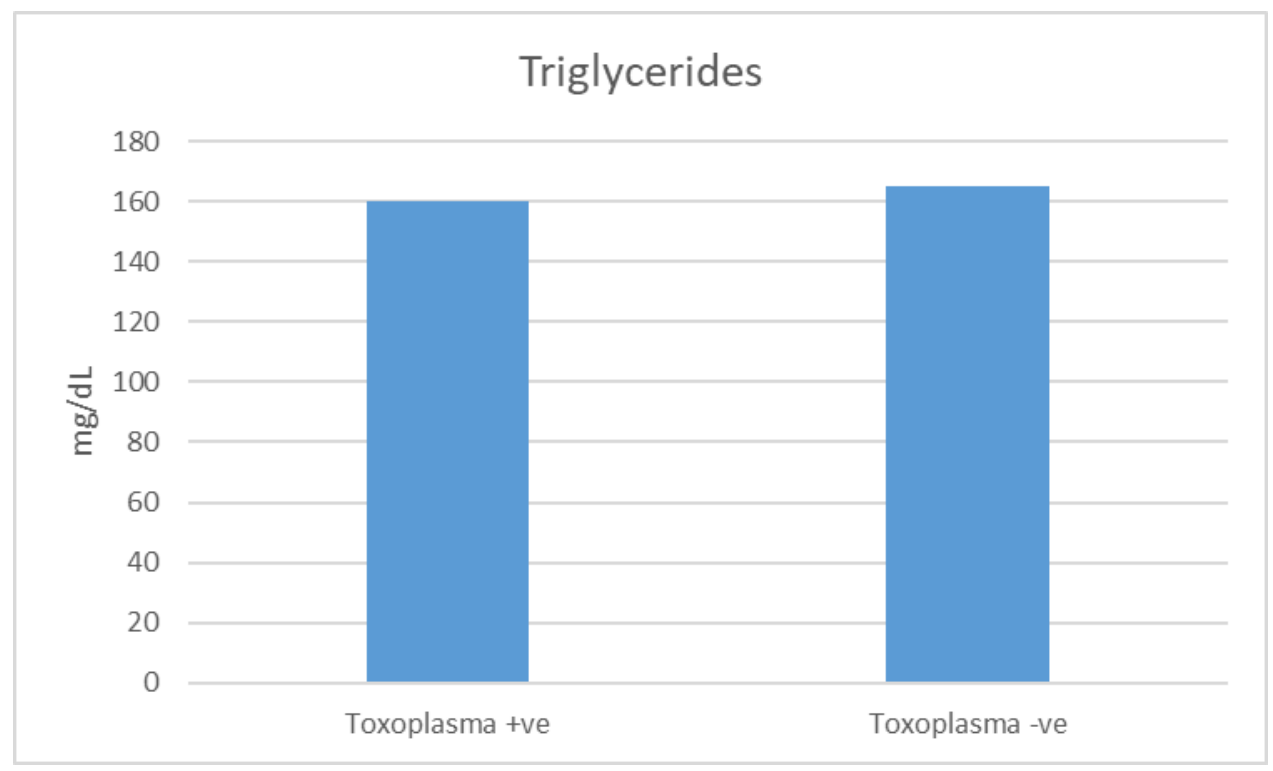

Figure 2-Triglyceride levels in Toxoplasma positive and Toxoplasma negative subjects. 
Table 2- Triglycerides levels in Toxoplasma +ve and Toxoplasma -ve subjects in relation to age groups.

\begin{tabular}{|c|c|c|r|r|r|r|}
\hline Age/years & otal & $\begin{array}{l}\text { Toxoplasma }+ \\
\text { ve }\end{array}$ & $\begin{array}{c}\text { Mean } \\
\text { triglycerides } \\
\text { level(mg/dL) }\end{array}$ & $\begin{array}{c}\text { Toxopl } \\
\text { asma }- \text { ve }\end{array}$ & $\begin{array}{c}\text { Mean } \\
\text { triglycerides } \\
\text { level (mg/dL) }\end{array}$ & $\begin{array}{c}\text { p- } \\
\text { value }\end{array}$ \\
\hline $18-25$ & 5 & 7 & 182 & 8 & 182 & 89 \\
\hline $26-35$ & 3 & 12 & 158 & 11 & 159 & 99 \\
\hline $36+$ & 1 & 2 & 105.5 & 9 & 160.8 & 82 \\
\hline
\end{tabular}

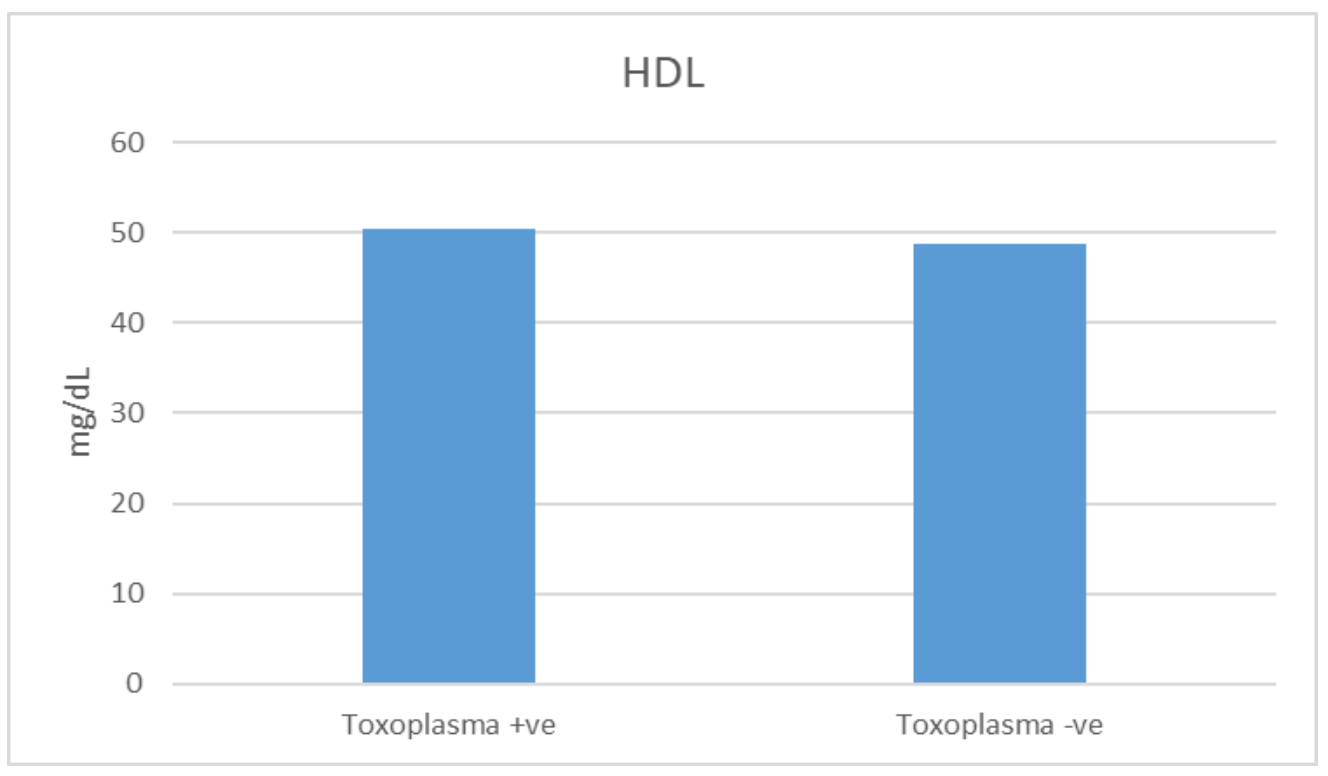

Figure 3-HDL levels in Toxoplasma positive and Toxoplasma negative subjects.

Table 3- HDL levels in Toxoplasma +ve and Toxoplasma -ve subjects in relation to age groups.

\begin{tabular}{|c|c|c|r|r|r|r|}
\hline $\begin{array}{c}\text { Age/y } \\
\text { ears }\end{array}$ & otal & $\begin{array}{c}\text { Toxopl } \\
\text { asma }+ \text { ve }\end{array}$ & $\begin{array}{c}\text { Mean } \\
\text { level(mg/dL) }\end{array}$ & $\begin{array}{c}\text { Toxopl } \\
\text { asma-ve }\end{array}$ & $\begin{array}{c}\text { Mean } \\
\text { HDL level } \\
\text { (mg/dL) }\end{array}$ & $\begin{array}{c}\mathrm{p} \\
\text {-value }\end{array}$ \\
\hline $18-25$ & 5 & 7 & 51.75 & 8 & 46.22 & 0 \\
\hline $26-35$ & 3 & 12 & 55.09 & 11 & 53.79 & 0 \\
\hline $36+$ & 1 & 2 & 49.9 & 9 & 51.9 & .65 \\
\hline
\end{tabular}




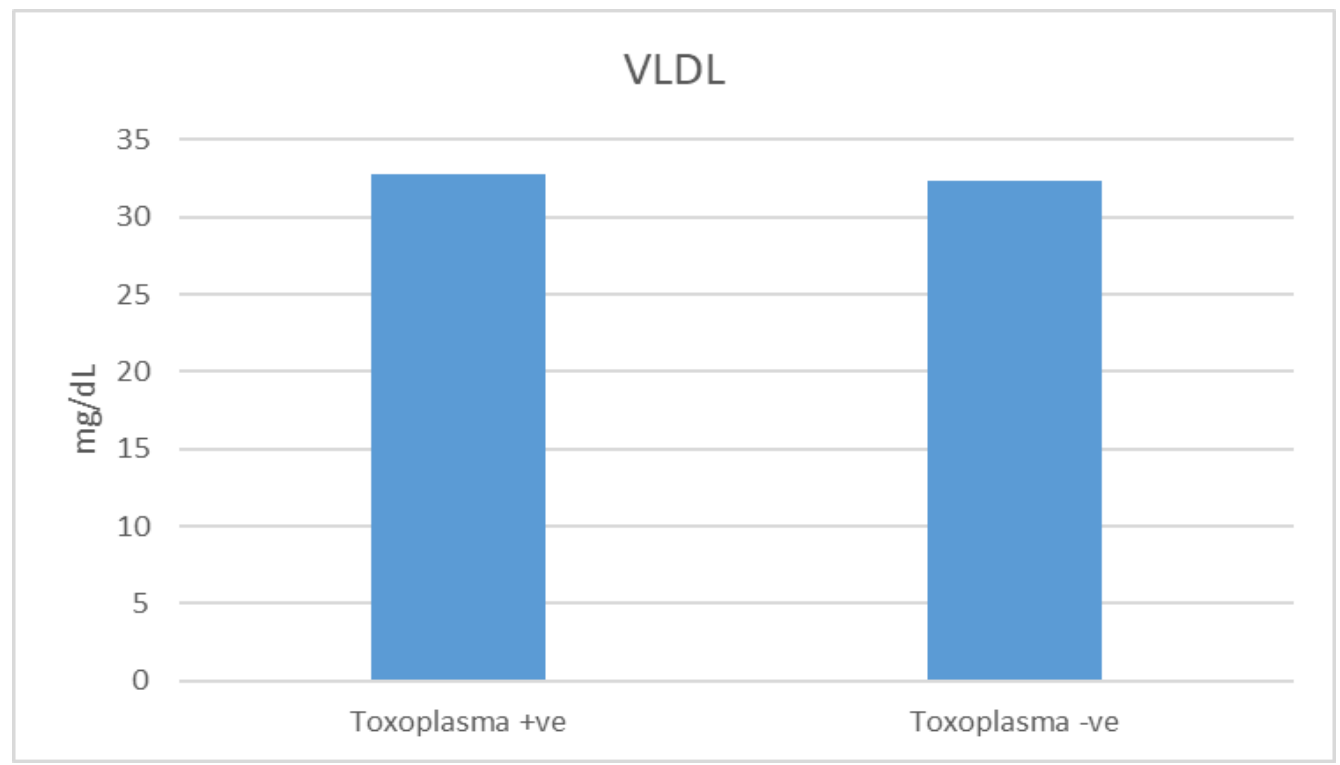

Figure 4-VLDL levels in Toxoplasma positive and Toxoplasma negative subjects.

Table 4- VLDL levels in Toxoplasma +ve and Toxoplasma-ve subjects in relation to age groups.

\begin{tabular}{|l|c|c|r|r|r|r|}
\hline $\begin{array}{c}\text { Age } \\
\text { /years }\end{array}$ & otal & $\begin{array}{c}\text { Toxopl } \\
\text { asma }+v e\end{array}$ & $\begin{array}{c}\text { Mean } \\
\text { VLDL } \\
\text { level(mg/dL) }\end{array}$ & $\begin{array}{c}\text { Toxopl } \\
\text { asma }-v e\end{array}$ & $\begin{array}{c}\text { Mean } \\
\text { VLDL level } \\
\text { (mg/dL) }\end{array}$ & -value \\
\hline $18-25$ & 15 & 7 & 36.3 & 8 & 42.9 & 0.47 \\
\hline $26-35$ & 3 & 12 & 31.7 & 11 & 36.3 & 0.45 \\
\hline $36+$ & 1 & 2 & 30 & 9 & 30.3 & 0.96 \\
\hline
\end{tabular}

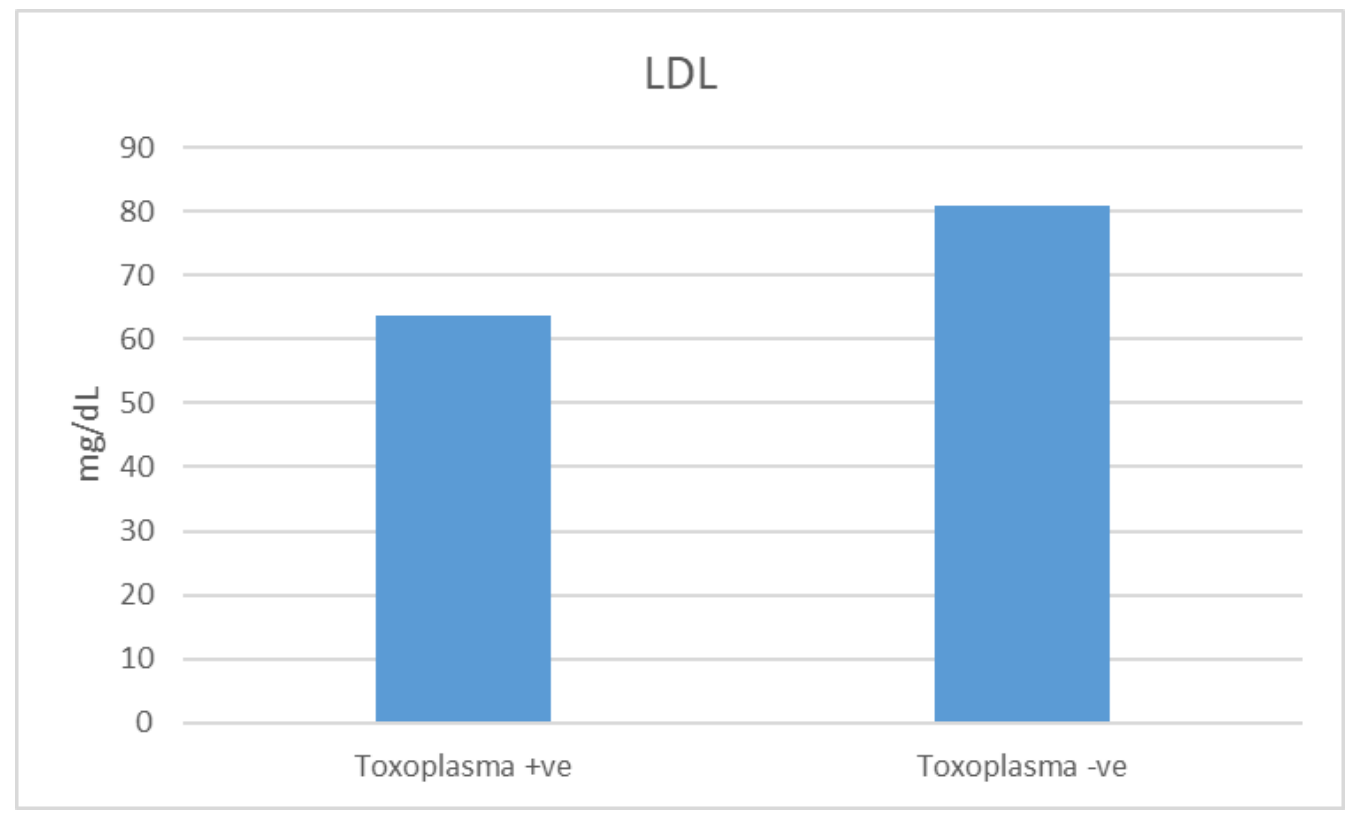

Figure 5-LDL levels in Toxoplasma positive and Toxoplasma negative subjects. 
Table 5- LDL levels in Toxoplasma +ve and Toxoplasma-ve subjects in relation to age group

\begin{tabular}{|l|c|r|r|r|r|l|}
\hline $\begin{array}{c}\text { Age } \\
\text { /years }\end{array}$ & otal & $\begin{array}{c}\text { Toxopl } \\
\text { asma }+ \text { ve }\end{array}$ & $\begin{array}{r}\text { Mean } \\
\text { LDL } \\
\text { level(mg/dL) }\end{array}$ & $\begin{array}{r}\text { Toxopl } \\
\text { asma }- \text { ve }\end{array}$ & $\begin{array}{r}\text { Mea } \\
\text { n LDL level } \\
\text { (mg/dL) }\end{array}$ & \multicolumn{1}{c|}{-value } \\
\hline $18-25$ & 5 & 7 & 55.2 & 8 & 101 & 0.17 \\
\hline $26-35$ & 3 & 12 & 64.6 & 11 & 78.1 & 0.25 \\
\hline $36+$ & 1 & 2 & 47.4 & 9 & 62.8 & 0.42 \\
\hline
\end{tabular}

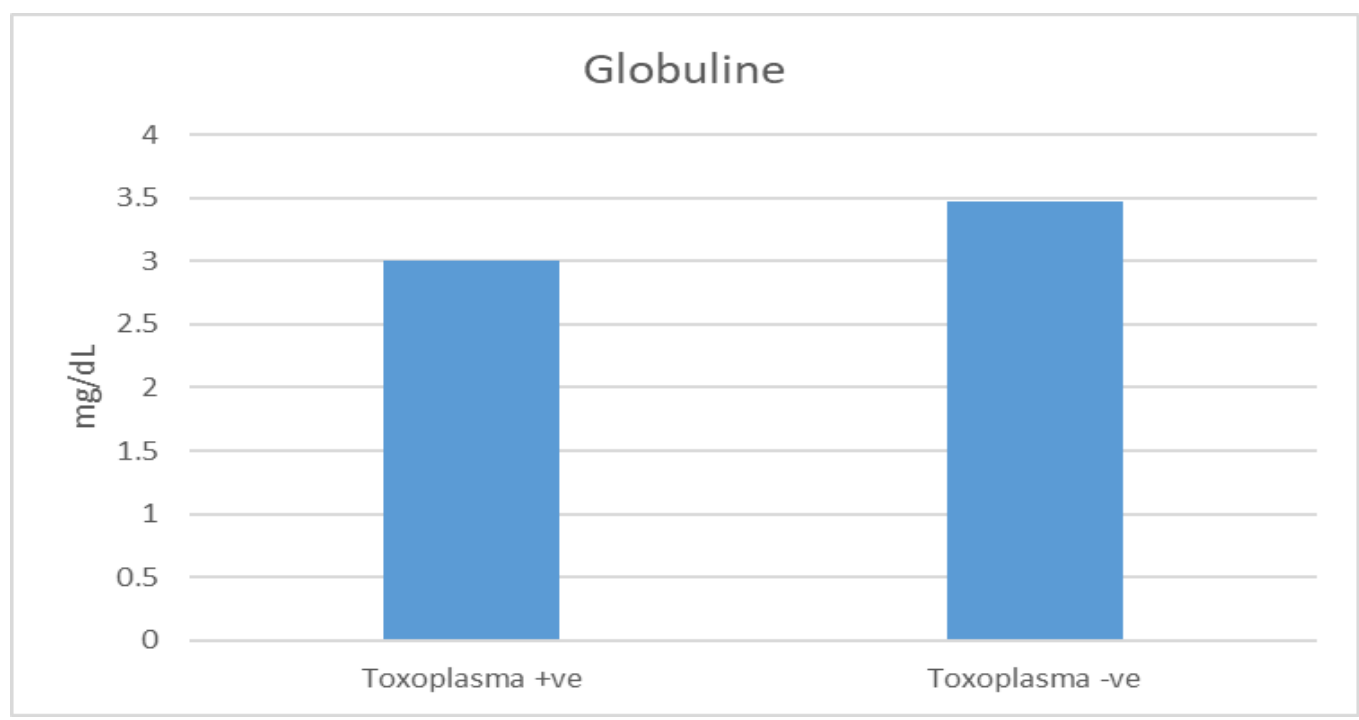

Figure 6-Globulin levels in Toxoplasma positive and Toxoplasma negative subjects.

Table 6- Globulin levels in Toxoplasma +ve and Toxoplasma-ve subjects in relation to age groups.

\begin{tabular}{|l|c|c|r|r|r|l|}
\hline $\begin{array}{c}\text { Age } \\
\text { /years }\end{array}$ & otal & $\begin{array}{c}\text { Toxopl } \\
\text { asma }+v e\end{array}$ & $\begin{array}{r}\text { Mean } \\
\text { globulin } \\
\text { level(g/dL) }\end{array}$ & $\begin{array}{r}\text { Toxopl } \\
\text { asma }-v e\end{array}$ & $\begin{array}{r}\text { Mean } \\
\text { globulin level } \\
\text { (g/dL) }\end{array}$ & -value \\
\hline $18-25$ & 5 & 7 & 3.02 & 8 & 3.48 & 0.22 \\
\hline $26-35$ & 3 & 12 & 2.88 & 11 & 3.58 & 0.023 \\
\hline $36+$ & 1 & 2 & 3.17 & 9 & 3.20 & 0.95 \\
\hline
\end{tabular}




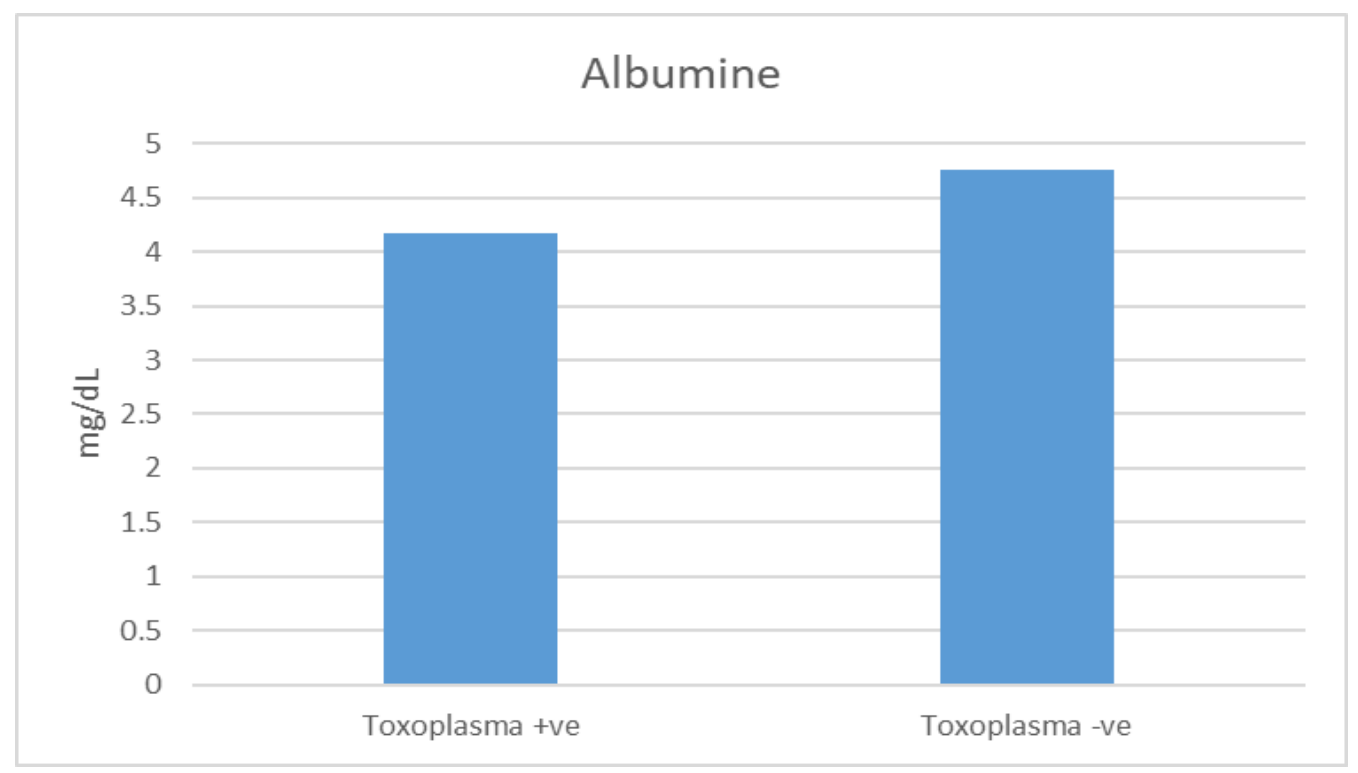

Figure 7-Albumin levels in Toxoplasma positive and Toxoplasma negative subjects.

Table 7- Albumin levels in Toxoplasma +ve and Toxoplasma-ve subjects in relation to age groups

\begin{tabular}{|c|c|c|c|c|c|c|}
\hline Age/years & otal & $\begin{array}{l}\text { Toxop } \\
\text { lasma }+ \text { ve }\end{array}$ & $\begin{array}{l}\quad \text { Mean } \\
\text { Albumin } \\
\text { level }(\mathrm{g} / \mathrm{dL})\end{array}$ & $\begin{array}{r}\text { Toxop } \\
\text { lasma-ve }\end{array}$ & $\begin{array}{l}\quad \text { Mean } \\
\text { Albumin } \\
\text { level(g/dL) }\end{array}$ & -value \\
\hline $18-25$ & 5 & 7 & 4.88 & 8 & 4.1 & .026 \\
\hline $26-35$ & 3 & 12 & 4.76 & 11 & 4.01 & .0065 \\
\hline $36+$ & 1 & 2 & 4.40 & 9 & 4.1 & .49 \\
\hline
\end{tabular}

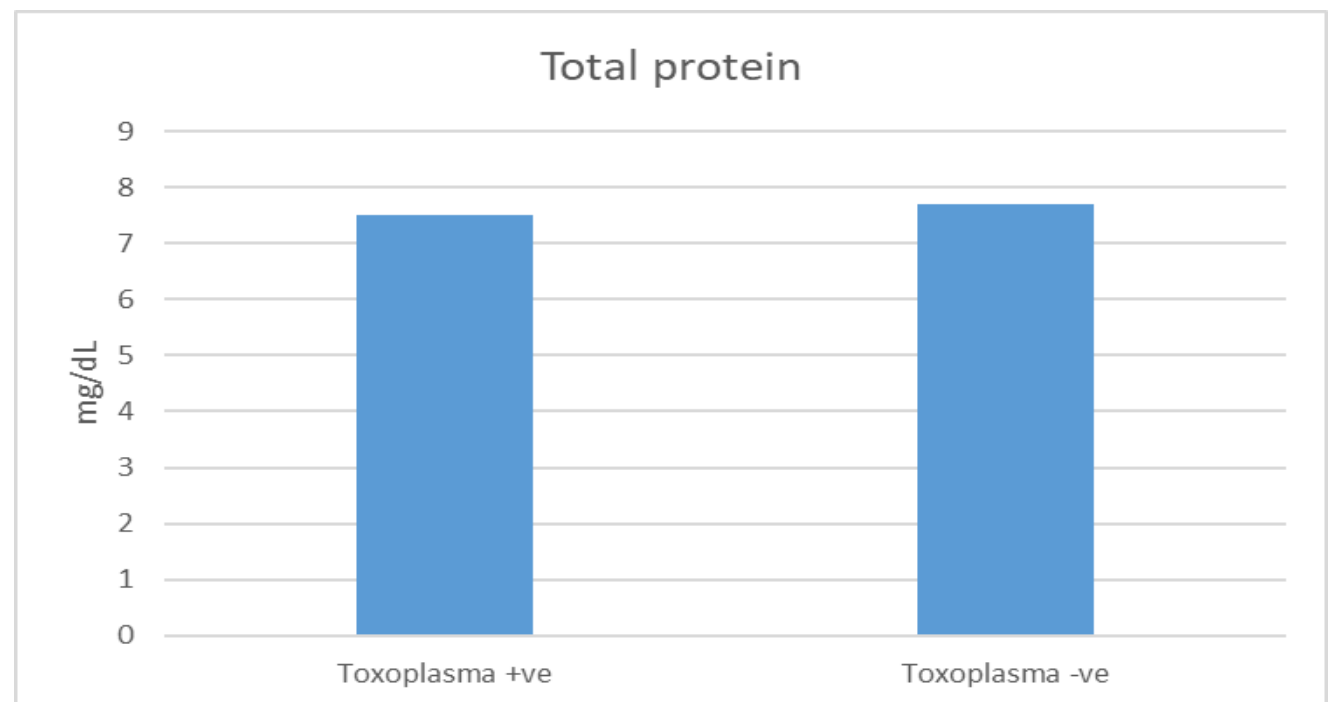

Figure 8-Total protein levels in Toxoplasma positive and Toxoplasma negative subjects. 
Table 8- Total protein levels in Toxoplasma +ve and Toxoplasma -ve subjects in relation to age groups.

\begin{tabular}{|l|l|c|c|c|c|c|}
\hline /years & Age & $\begin{array}{c}\text { Toxopl } \\
\text { asma }+ \text { ve }\end{array}$ & $\begin{array}{c}\text { Mean } \\
\text { total } \\
\text { protein }\end{array}$ & $\begin{array}{r}\text { Toxopl } \\
\text { level(g/dL) }\end{array}$ & $\begin{array}{c}\text { Mean } \\
\text { protein }\end{array}$ & -value \\
\hline $18-25$ & 5 & 7 & 7.9 & 8 & 7.2 & .06 \\
\hline $26-35$ & 3 & 12 & 7.69 & 11 & 7.60 & 0.37 \\
\hline $36+$ & 1 & 2 & 7.56 & 9 & 7.61 & 0.47 \\
\hline
\end{tabular}

\section{Discussion}

This investigation demonstrated interesting results approving that $T$. gondii alters some biochemical parameters. The results of lipid profile indicated a drop in cholesterol and triglycerides levels and the grade of lipid peroxidation, as characterized by a significant increase in HDL.

The association between the concentrations of cholesterol in people infected with some parasites has attracted the consideration of various researchers. Toxoplasma is incapable of synthesize cholesterol de novo and relies on recovering LDL-derived cholesterol from the host cell through LDLmediated endocytosis or protein linked to the LDL receptor [13]. A mechanism has been proposed to control the entry of toxoplasma into cells by host and not parasite cholesterol [14]. These investigations revealed that cholesterol has a significant part in pathogenesis of $T$. gondii infection. However, facts on the lipid bases of $T$. gondii are very rare and the molecular tools by which Toxoplasma recovers lipids of the host cell are mostly unidentified [15]. Previous studies showed high concentrations of lipoproteins in people with protozoan infections [16]. Alterations in these lipoproteins were noticed in some other infections, as in HIV infected individuals who are under antiviral therapy [17]. Conflicting results were attained by other investigators, which might be attributed to the chronic nature of the disease, which is mostly the case in this study. However, in acute malaria infections, the levels of HDL and LDL were decreased, whereas that of triglycerides was increased temperately [18]. In another study, acute phase HDL was reported to be altered, with reduced HDL and antioxidant activity as well as other structural-compositional changes and inflammatory protein interactions [19]. A different study showed that the reason for the decline in HDL can be the hypertriglyceridemia-related acute phase response, which is an immediate response [20]. More investigations are needed to characterize the HDL particle during both the chronic and acute phases of toxoplasmosis. Finally, this study detected no significant differences in some parameters the lipid profile between the studied groups. This could be due to the limited number of cases.

These results are in disagreement with those of Yarim et al. [21], who observed hypoalbuminemia with a lower $A / G$ ratio in infected dogs. Low concentration of albumin suggests damaged functions of the liver. Many factors can influence the fluctuation of serum proteins, including parasites and other infectious diseases [22]. Previous animal research reported a decrease in serum albumin levels in experimentally infected Toxoplasma mice due to liver injury [23]. However, in the present study, all $T$. gondii seropositive patients did not show any clinical features related to liver damage. Therefore, albumin level did not show the decrease reported by other studies.

Finally, this study revealed that $T$. gondii has a role in altering some biochemical factors in infected women, as characterized by the decline in the levels of cholesterol, triglycerides, and LDL, with the obvious increase in HDL concentration. Further investigations are required to investigate the effects of the phases of toxoplasmosis (chronic versus acute) on the alterations of all these parameters.

\section{References}

1. Hosseini, S.A., Amouei, A., Sharif, M., Sarvi, S., Galal, L., Javidnia, J., Pagheh, A.S., Gholami, S., Mizani, A. and Daryani, A. 2019. Human toxoplasmosis: a systematic review for genetic diversity of Toxoplasma gondii in clinical samples. Epidemiology \& Infection, 147.

2. Chegeni, T.N., Sarvi, S., Moosazadeh, M., Sharif, M., Aghayan, S.A., Amouei, A., Hosseininejad, Z. and Daryani, A. 2019. Is Toxoplasma gondii a potential risk factor for Alzheimer's disease? A systematic review and meta-analysis. Microbial pathogenesis, 137: 103751.

3. Anvari, D., Sharif, M., Sarvi, S., Aghayan, S.A., Gholami, S., Pagheh, A.S., Hosseini, S.A., Saberi, R., Chegeni, T.N., Hosseininejad, Z. and Daryani, A. 2019. Seroprevalence of Toxoplasma 
gondii infection in cancer patients: a systematic review and meta-analysis. Microbial pathogenesis, 129: 30-42.

4. Jg, M., LieSenfeld O. 2004. Toxoplasmosis. Lancet, 363(9425): 1965-76.

5. Siponen, A.M., Kinnunen, P.M., Koort, J., Kallio-Kokko, H., Vapalahti, O., Virtala, A.M. and Jokelainen, P. 2019. Toxoplasma gondii seroprevalence in veterinarians in Finland: older age, living in the countryside, tasting beef during cooking and not doing small animal practice associated with seropositivity. Zoonoses and public health, 66(2): 207-215.

6. Assim, M.M. and Saheb, E.J. 2018. The Association of Severe Toxoplasmosis and Some Cytokine Levels in Breast Cancer Patients. Iraqi Journal of Science, : 1189-1194.

7. Nafal, R.H., Al-Warid, H.S. and Al-Sultan, H.J. 2019. Seroprevalence of Toxoplasmosis in patients with chronic liver disease in Baghdad. Iraqi Journal of Science, : 1667-1672.

8. Portugal, L.R., Fernandes, L.R., Pedroso, V.S.P., Santiago, H.C., Gazzinelli, R.T. and AlvarezLeite, J.I. 2008. Influence of low-density lipoprotein (LDL) receptor on lipid composition, inflammation and parasitism during Toxoplasma gondii infection. Microbes and Infection, 10(3): 276-284.

9. Bisanz, C., Bastien, O., Grando, D., Jouhet, J., Maréchal, E. and Cesbron-Delauw, M.F. 2006. Toxoplasma gondii acyl-lipid metabolism: de novo synthesis from apicoplast-generated fatty acids versus scavenging of host cell precursors. Biochemical Journal, 394(1): 197-205.

10. Bansal, D., Bhatti, H.S. and Sehgal, R. 2005. Role of cholesterol in parasitic infections. Lipids in health and disease, 4(1): 10.

11. Pisani, T., Gebski, C.P., Leary, E.T., Warnick, G.R. and Ollington, J.F. 1995. Accurate direct determination of low-density lipoprotein cholesterol using an immunoseparation reagent and enzymatic cholesterol assay. Archives of pathology \& laboratory medicine, 119(12): 1127-1135.

12. Riond, B., Wenger-Riggenbach, B., Hofmann-Lehmann, R. and Lutz, H. 2009. Serum protein concentrations from clinically healthy horses determined by agarose gel electrophoresis. Veterinary clinical pathology, 38(1): 73-77.

13. Coppens, I., Sinai, A.P. and Joiner, K.A. 2000. Toxoplasma gondii exploits host low-density lipoprotein receptor-mediated endocytosis for cholesterol acquisition. The Journal of cell biology, 149(1): 167-180.

14. Milovanović, I., Vujanić, M., Klun, I., Bobić, B., Nikolić, A., Ivović, V., Trbovich, A.M. and Djurković-Djaković, O. 2009. Toxoplasma gondii infection induces lipid metabolism alterations in the murine host. Memórias do Instituto Oswaldo Cruz, 104(2): 175-178.

15. Milovanovic, I., Trbovich, A.M., Vujanic, M., Klun, I., Bobic, B., Nikolic, A., Ivovic, V. and Djurkovic-Djakovic, O. 2008. Toxoplasma gondii infection induces lipid metabolism alterations in the murine host. International Journal of Infectious Diseases, 12: e172-e173.

16. Faucher, J.F., Ngou-Milama, E., Missinou, M., Ngomo, R., Kombila, M. and Kremsner, P.G. 2002. The impact of malaria on common lipid parameters. Parasitology research, 88(12): 10401043.

17. Funderburg, N.T. and Mehta, N.N. 2016. Lipid abnormalities and inflammation in HIV infection. Current HIV/AIDS Reports, 13(4): 218-225.

18. Dias, R.M., Vieira, J.L.F., Cabral, B.D.C., da Silva, I.R.P., Brasil, L.M.B.F., Araújo, E.D.C. and de Andrade, M.A. 2016. Lipid profile of children with malaria by Plasmodium vivax. Journal of tropical medicine, 2016.

19. Brites, F., Martin, M., Guillas, I. and Kontush, A. 2017. Antioxidative activity of high-density lipoprotein (HDL): Mechanistic insights into potential clinical benefit. BBA clinical, 8: 66-77.

20. Al-Kateeb, S.M., Hasan, H.H. and Al-Kuraishi, A.H. 2013. Lipid profile changes in Toxoplasmosis aborted women. Baghdad Science Journal, 10(1): 168-175.

21. Yarim, G.F., Nisbet, C., Oncel, T., Cenesiz, S. and Ciftci, G. 2007. Serum protein alterations in dogs naturally infected with Toxoplasma gondii. Parasitology research, 101(5): 1197-1202.

22. Bernardi, M., Maggioli, C. and Zaccherini, G. 2012. Human albumin in the management of complications of liver cirrhosis. Critical Care, 16(2): 211.

23. He, J.J., Ma, J., Elsheikha, H.M., Song, H.Q., Huang, S.Y. and Zhu, X.Q. 2016. Transcriptomic analysis of mouse liver reveals a potential hepatoenteric pathogenic mechanism in acute Toxoplasma gondii infection. Parasites \& vectors, 9(1): 427. 